\title{
In praise of the 'brain drain'
}

\section{Countries and professions that export skilled staff do not always lose out.}

G overnments and scientists are often heard expressing angst about the malign impact on their countries of the 'brain drain', the flow of skilled individuals to foreign climes. The brain drain worries people everywhere, with the possible exception of California. It is a policy fixation in European science, a concern for at least three-quarters of American states, and, most of all, a major strategic headache for developing countries.

In South Africa, for example, the government has demonized institutions that train doctors and nurses who leave for employment elsewhere. It has taken steps to penalize those state-trained health professionals who choose to leave.

But South Africa is wrong. Its perception of the brain drain - as a simple transaction in which the recipient gains and the donor loses - is, at best, incomplete. Conventional wisdom holds that the movement of trained healthcare personnel from Africa is creating a crisis in public health. But is that really what is happening?

Michael Clemens, an economist at the non-partisan Center for Global Development in Washington DC, doesn't think so. He reported his findings at the meeting of the American Association for the Advancement of Science in San Francisco last month (see www.cgdev. org/content/publications/detail/13123). There is a clear correlation between emigration and the state of the public healthcare system, but not the one you might expect. The higher the proportion of an African nation's nurses and doctors who have moved abroad, the better shape its healthcare is likely to be in.

This is not so strange, when you think about it. Countries and professions with more openness and greater mobility of personnel are more likely to be in touch with global trends - and more likely to attract able trainees in the first place. The worst public healthcare systems, Clemens says, are in French-speaking West Africa, where staff are least likely to emigrate, as France won't let them.

The tendency of perhaps half of today's emigrants to return home later on in their careers is another factor. So is remuneration and the large amounts of cash that migrants send back home. These changes make the old model of immigrant 'donor' societies obsolescent. Communities can benefit, financially and intellectually, from those who have left. It is the degree to which these benefits counteract the unquestionable initial loss that is open to question.

Similar observations could be made regarding emigration flows between wealthy nations. According to the World Bank, Britain has more professional émigrés than any nation on Earth. But it doesn't seem to be hurting. California's research labs may be crawling with Brits, yet UK science has gone from strength to strength. According to surveys of citations against expenditure, Britain has one of the most productive research systems in the world. How can this be?

Well, say the revisionists, science departments at British universities may actually benefit from the ambition to depart, and, to a lesser degree, from their connections with those who have done so. Perish the thought, but some of these mobile researchers may even do the best work of their lives at Salford, say, only to take their foot ever-soslightly off the gas when they 'arrive' at Stanford.

Woody Allen once observed that the sole cultural advantage of California (over his native New York, presumably) was its law permitting you to turn right at a red light. To be fair, science and industry in the Golden State have clearly benefited to a massive degree from immigrant talent gleaned from every corner of the planet. But the notion that other places have necessarily suffered a corresponding loss - or that emigration is a zero-sum game - is misplaced.

\section{The legacy of Linnaeus}

\section{Taxonomy in an age of transformation.}

E very plant and animal has a mitochondrial cytochrome oxidase I gene, and its sequence helps researchers assign that plant or animal to a given species, with some degree of certainty. The precise degree of the certainty obtained using this 'barcode' sequence is a matter of some debate, but such sequences are clearly useful to both taxonomists and those who use applied taxonomy. And the industrialscale sequencing that allowed Craig Venter's ocean-metagenomics consortium to deposit billions of letters of sequence from hundreds of thousands of microbe genes into the GenBank database this week opens up even more possibilities.

The ability to peer into living things and inspect the evolutionary scorecard encoded in their genes has transformed the whole of biology, but few fields have had their core assumptions challenged

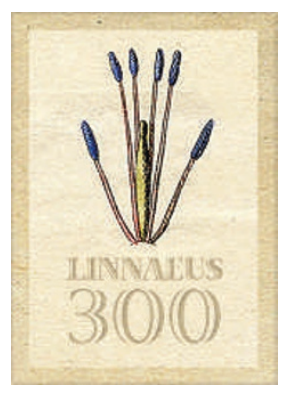

as deeply as taxonomy. From the time of Carl Linnaeus, born 300 years ago this May, taxonomy has relied on the observation and comparison of physical forms. Now it is supplemented by access to what would once have been seen not as form, but as essence.

Linnaeus himself sought a universal classification of all creation, animal, vegetable and mineral. His categorizations were not uniformly valuable, but his systematic spirit, his stress on the concept of species, and the formal but adaptable conventions of nomenclature he introduced have endured. Nature is glad to celebrate his legacy in this special issue.

DNA sequencing is a gift that Linnaeus would surely have made great use of, but it brings its own problems. It is not always easily reconciled with the careful description, annotation and curation that have been the duty and delight of the taxonomists who carried the linnaean programme forward. The availability of DNA sequences 